\title{
The role of urban religion in seeking peace beyond the mere absence of community conflict: A reading of Ephesians 2:11-22, with the homeless in the City of Tshwane
}

\author{
Author: \\ Reginald W. Nel ${ }^{1}$ \\ Affiliation: \\ ${ }^{1}$ Department of Christian \\ Spirituality, Church History \\ and Missiology, University of \\ South Africa, South Africa \\ Correspondence to: \\ Reggie Nel \\ Email: \\ rwnel@unisa.ac.za \\ Postal address: \\ PO Box 392, University of \\ South Africa, Pretoria 0003, \\ South Africa \\ Dates: \\ Received: 27 July 2015 \\ Accepted: 11 Aug. 2015 \\ Published: 26 Oct. 2015 \\ How to cite this article: \\ Nel, R.W., 2015, 'The role \\ of urban religion in seeking \\ peace beyond the mere \\ absence of community \\ conflict: A reading of Eph \\ 2:11-22, with the homeless \\ in the City of Tshwane', \\ HTS Teologiese Studies/ \\ Theological Studies 71(3), \\ Art. \#3128, 8 pages. http:// \\ dx.doi.org/10.4102/hts. \\ v71i3.3128

\section{Copyright:} \\ C 2015. The Authors \\ Licensee: AOSIS \\ OpenJournals. This work is \\ licensed under the Creative \\ Commons Attribution \\ License.
}

Read online:

Scan this QR
code with your
smart phone or
mobile device
to read online.

Urban religion, often visible in the work of faith-based organisations which consciously aim at unshackling the debilitating realities of urban marginalised communities, needs to be consciously inclusive in all its endeavours. In particular, this is crucial for actions such as those of the Tshwane Leadership Foundation that consciously seeks the peace of the city beyond the mere absence of conflict. This inclusivity requires a sensitive, creative, but also mutually transformative dialogue. This article aims at bringing into dialogue what biblical scholar Gerald West, in his proposal for contextual Bible Study, calls 'trained' readers of the Bible with what he calls 'ordinary' readers, who are homeless in the City of Tshwane. This methodology leads to a mutually transformative encounter in the common search for peace but also to appreciating the calling of urban religious communities in South Africa. It aims to make a contribution towards an inclusive and mutually transformative dialogue in order to contribute to the quest of urban religious communities to unshackle the marginalisation, whether it be in their consciousness or their environment.

\section{Introduction}

People who end up homeless in the streets of cities like the City of Tshwane (hereafter called Tshwane) often had to flee from their homes because of conflict and violence. Tragically, they end up in new marginalised situations - again as the targets or victims of violence (James 2008:63-65; Orobator 2005:143f.). In 2003, a group of teenagers from the prestigious Waterkloof High School went out one night in this city and simply kicked such a homeless, nameless man to death (Rademeyer 2007:6). In 2008, it was groups of mostly young men from various urban townships that turned on uprooted migrants. In the work Go home or die here: Violence, xenophobia and the reinvention of difference in South Africa (Hassim, Kupe \& Worby 2008), which analyses this eruption of violence, Alex Eliseev (2008:27-39) entitles his contribution 'A torn narrative of violence'.

In the Meals-of-Peace project (MOP) in partnership with various faith-based non-governmental organisations (NGOs) like the Tshwane Leadership Foundation (TLF), the notion of seeking peace in the context of 'urban transformation' and 'building healthy urban communities ... in ways that are radically inclusive socially and economically' (TLF) are central in order to unshackle urban communities from these traumatic, debilitating and oppressive experiences. Of importance for this religious urban presence and therefore also for missional congregational praxis is how religious communities, in particular theologians and ministers, would engage with these marginalised urban communities while respecting their (the communities') own agency in maintaining dignity or simply fending for their (the communities') lives. When Mangayi (2014:214-218) refers to the communities of city-dwellers, he highlights the intertwinement of poverty, marginalisation and exclusion. Urban religion and therefore also urban public theology or urban missiology must consequently wrestle with the question of how to ensure that seeking peace and the aforementioned references to 'urban transformation' and 'radical inclusion' (by TLF) remain integral to its methodology for what we broadly call a postcolonial urban theology. The MOP project in particular aims to consciously affirm the voices of what West calls 'ordinary' readers (West 1993:8) who, in this project, are a group of homeless readers in Tshwane. In explaining this methodology, in particular the notions of 'trained' (see also Segovia [1999:179] which refers to the 'scientific reader' whilst West [2001:172] himself refers later to 'socially engaged Biblical scholars') and 'ordinary' readers, West (1993:13-14) roots his conceptualisation in a decision to consciously read the Bible contextually from the perspective of the poor, marginalised or oppressed. He acknowledges the following: 
For those of us who are not from among the poor and oppressed this may seem a difficult commitment ... In addition, those of us who have been theologically and biblically trained [the trained readers] usually find is hard to genuinely hear and learn from ordinary readers of the Bible. We have to honestly believe that we can learn from the readings of ordinary people. So for us reading the Bible with ordinary readers requires something of a conversion experience; we need to be converted to a sense of community consciousness. (West 1993:14-15)

Hence, the homeless community are recognised in this contextual Bible-study methodology not simply as the objects of the well-meaning mission outreaches of congregations but as authentic bearers of witness to the gospel, able to continue a creative dialogue or 'transformative encounters' (Kritzinger 2008:764-790; Mashau \& Kritzinger 2014:10-13) and often challenging possible hegemonic, elite readings of the religious text and the context. By so doing, this project and therefore this article may respond to the possibly subtle-yet-devastating forms of exclusion (and violence) in old and recurring forms of discourses (Segovia 1999:182f.; Sugirtharajah 2003:3-4, 15-16).

In this contribution, then, I firstly present two proposals on how the quest for peace by faith communities is interpreted. It was hoped at the time that these readings would influence the role of preachers in and members of faith communities on how to relate to their context. My examples are taken from the Reformed tradition and are limited, with the purpose of engaging this tradition. This limited focus has the potential to unmask but also to begin to address the historical burden of this religious tradition as it was the one which officially provided theological justification for the apartheid system. The examples come at a time when there is an attempt to disentangle the Reformed tradition biblically and theologically from apartheid theology, and it consciously makes an attempt at an alternative reading. Secondly, I reflect on these readings by relating them to the question of peace as a theologian challenged, amongst others, by South-African Black theology within the specific historical and structural realities of South-African cities like Tshwane. This city was constructed as part of a broader colonial project (Bekker 1991:109-112; Davenport 1991:1-18; Kgatla 2013:120-132; Mashau 2014:192-199). It seems that, despite the emergence of what is popularly known as the 'new South Africa' or the 'democratic South Africa', these historical realities continue to challenge its newcomers, whether they seek refuge or employment in their quest for economic emancipation, as I shall show later. The recent explosion of violence in various South African cities, some argue (Landau 2008:106; Silverman \& Zack 2008:147-159), is a combination of the consequence of this legacy and some inadequate post-colonial policy making. Authentic and deep liberation, or what we would call the radical unshackling of the poor urban communities, needs to take this into account. Thirdly, the article brings the voices 'from the pavements' (Mashau \& Kritzinger 2014:10-11) which challenge and subvert the (our) trained readings into a postcolonial missiological and ultimately transformative encounter. This article concludes, lastly, with pointers for an alternative reading of these texts as we unshackle the burdens of the particular past in relation to urban communities.

\section{Seeking peace in the city}

What would peace mean for urban communities in South Africa? Narrowing the question down to the role of religious communities, in particularly the Christian church, I focus on the readings of the Christian tradition's religious texts, namely the Bible, as presented in scholarly guidelines for preaching, Bible studies and general reflections for study groups. Whilst this is not a new question, from a South African context, the emphasis on the role of religious communities in seeking peace (also for urban realities like Tshwane) has started to surface more pointedly in the late 1980s and early 1990s in various guidelines and reflections for leaders and members preaching and leading Bible studies in the Nederduitse Gereformeerde [Dutch Reformed] churches. In this section, I present two examples to indicate how readings of religious texts aimed at shaping and guiding a particular religious role in seeking peace. This section concludes with some critical reflections as a bridge to the section on the readings from the pavements.

I now present a contribution of guidelines for sermon preparation and preaching from the 'Word against the Light' series, in particular the publication focused on peace called Guidelines for preaching about peace (Burger, Müller \& Smit 1990), and a collection of reflections and Bible studies from various South African missiologists, called The interests of the city (Van Rooyen 1993).

\section{'Guidelines for preaching about peace'}

In their introduction, Burger et al. (1990) explain that, whilst they have planned and conceptualised their series ten years earlier (in 1980), they never realised how relevant the theme of seeking peace would become later. They refer to the many peace initiatives by churches; the official peace year declared in the congregations, presbyteries and synod of the Nederduitse Gereformeerde Sendingkerk (NGSK); the difficult unification process between the NGSK and the Nederduitse Gereformeerde Kerk in Afrika (NGKA) at the time and the contribution of the Nederduitse Gereformeerde Kerk (NGK) in the Western-Cape in a research project on the role of the church in seeking peace. They also refer to what they call the various peace initiatives in the country's politics, namely, the release of (political) prisoners, the unbanning of organisations and the opening up of negotiations. Seeking peace seems to have been considered as critical for the time.

In his introduction to this theme of preaching about peace, De Villiers (1990:11-20) also refers to these realities. He places it within the broader media focus on the coming together of the United States of America and the Soviet Union (after the ColdWar era) and, in South Africa, on the long violent conflict 
between the government and black political organisations. This, according to De Villiers, points to an intense desire amongst all South Africans for peace to come to this country and the world. For him, however, the fundamental reason for the focus on preaching about peace should be because peace and the endangerment of peace is one of central themes of the Bible (De Villiers 1990:11). He consequently starts from the first two chapters of Genesis which paint a picture of harmony between God and humanity, amongst humanity itself, amongst humanity and nature, as well as amongst nature. This perfect picture of harmony is ruptured with the fall into sin, which is the deepest cause for all alienation and conflict in the world. This cycle, De Villiers points out, is repeated in the rest of the Old and New Testaments of the Bible with the history moving along towards a futuristic perfect reign of peace in and through the person, action and second coming of Jesus Christ. For him, the fundamental question is what to say in the preaching about peace and how to seek peace (De Villiers 1990:12).

In answering this question, De Villiers then cautions against a set of rules for all preaching, but he points to general comments to be taken into account. Firstly, peace, in continuation with the Old Testament message and expectation of 'shalom', needs to be understood as comprehensive. It is understood as not merely the cessation of military conflict or a narrow inner rest for the soul. Rather, peace as shalom is the comprehensive condition of social harmony and material well-being in society (De Villiers 1990:12). In this understanding, however, shalom is only present where God is worshipped correctly and obeyed. Shalom includes nature, and this message is also to be found in the New Testament. In the New Testament, it is proclaimed that Jesus Christ reconciled the whole world with God through the cross so that there is now peace, according to Romans 5:1 (De Villiers 1990:13). This deed of reconciliation leads to the existence of a new community, the church, but it also has cosmic implications. Because of this, believers are to be peacemakers in this comprehensive sense of the word.

Secondly, for De Villiers, there is an eschatological dimension to peace. A reign of peace is promised, not only for the people of Israel but for all nations. This is a cyclical return to paradise - where there was perfect harmony. The core of the New Testament's message on peace is that the prophecy of a messianic reign of peace is fulfilled in the person and actions of Jesus Christ, but the second coming will usher in the 'new heaven and earth' where there will be no sin, want, injustice, sickness or death - a perfect restoration (De Villiers 1990:14). In preaching, De Villiers argues, this is accomplished by critical preaching on any human efforts at claiming that it can guarantee a comprehensive and perfect peace. He also refers to preaching which, in the midst of dire situations of war end violence, keeps the hope for peace alive.

Thirdly, De Villiers (1990:14) emphasised that there can be no peace without justice. He underlines the Old-Testament intertwinement between peace and justice and the point that there can be no peace in communities or societies where there are people who suffer want or who are exploited or oppressed. He explains his views as follows:

True peace includes the true worship of God and this true worship of God in turn includes the special care for the poor, the weary and the oppressed in society (cf. is 58:6-7). (De Villiers 1990:14)

This vision is for all nations and was (again) fulfilled in the death of Jesus Christ. Believers must therefore never share these privileges with an exclusive group only but with everybody.

Fourthly, peace does not come through military means or war but through God and his Spirit (De Villiers 1990:15). God do this through the suffering servant, Jesus Christ, who took the sin upon himself and who set the example for believers on how to practice their search for peace. It is not to be done through retribution but through forgiving the injustice done to them and through the pursuit of a journey of love and tolerance (De Villiers 1990:15).

Lastly, De Villiers warns that a direct application of verses (related to peace) within any situational analysis cannot be allowed. This is a grave temptation for preachers. However, De Villiers reminds his readers, namely modern preachers, of the vast chasm between the context of the biblical authors and themselves as the readers. He refers to the examples of the crusades and their so-called, 'holy wars'. What is needed is a careful analysis of the particular circumstances of the first readers of the text and also of the readers of today. He (De Villiers 1990:16) speaks of a careful and unbiased analysis, warns against the danger of a 'one-sided and prejudicial view' and mentions the examples in South Africa of two conflicting and different explanations for the threat to peace. On the one hand, he refers to white people, who put the blame for the unrest squarely on communist agitators. This explanation lead to more stringent security measures and protection against the communist ideology. On the other hand, one finds an explanation from black people, who blamed apartheid for the conflict. The revolutionary violence, in their view, was a result of the 'structural violence' of various kinds of discriminatory measures in society. Preachers from these two different camps, De Villiers (1990:16) argues, then choose different (useful) texts from the Bible and come to different applications. This is for him an expression of ideological preaching which uses the Bible to justify the own analysis of the conflict and the measures for their version of peace. This ideological stance can be prevented through an open listening to the other's view and a willingness to change the own view. Preaching must, on the basis of the word of God, expose bias and prejudice and test them critically. This kind of preaching, for De Villiers (1990:17-18), is a sign of openness to the prophetic action of God's word. He then lists various literature sources that might of relevance for the preaching on peace.

I now turn to the second example from a group of trained readers on seeking the peace of the city as seeking its (the city's) interests. 


\section{'The interests of the city'}

When Van Rooyen published a collection of reflections and Bible studies by missiologists Dawid Bosch, Dionne Crafford, Dons Kritzinger, Piet Meiring, Andries Odendaal and Hennie Pretorius (Van Rooyen 1993) on what they called the witnessing task of the church in a changing South Africa in 1993, the title he chose was The interests of the city. This focus on the city is in line with the emphasis at the time as Bakke (1989:42) also argues for what he calls '... the shifting frontiers of mission' to be '... a world that has gone from a world of nations to a world of interconnected multinational cities'. Bakke later refers to a conference of the Lausanne Committee for World Evangelisation in 1980 where the realisation dawned on 'how little was being done' (Bakke 1989:45) at that stage. In The interests of the city, it was Pretorius (1993:1-8) who, in the first Bible reflection, explained this focus on the basis of an exposition of a pericope in Jeremiah 29:1-7. I shall limit my focus to this biblical reflection.

For Pretorius, the main thrust of this text is that the Jews in exile are encouraged to seek the 'interests' of the Babylonian city. The word 'interests' are preferred here as his interpretation of the notion of 'shalom' in the particular text. Pretorius opens up this biblical reflection with reference to what he calls the 'the continuous toyi-toying, strikes, demands for more money, black on black violence' (Pretorius 1993:1; italics added), which creates an atmosphere of uncertainty and negativity also for mission. For him, the key challenge is to seek the will of God, to make Jesus Christ the king of the whole life and to ask about the congregation's missionary calling in South Africa. The Christian religion, he (Pretorius 1993:2) shows, asks that one allows for your whole life to be influenced by your faith in Jesus Christ, and therefore, Christians must go to their Bible to ask what they must do to the conditions of their town or city.

In doing so, Pretorius explains that the context of Jeremiah was alienating and terrifying because the Jews had sinned, and as punishment, they were exiled from Jerusalem to Babylon. The 'cream of the crop' was in exile, and they were charged to serve the interests of the Babylonian empire, being allowed many freedoms. They were now in a strange land and exposed to a strange culture, language and habits, which also included a heathen religion. They feared for their security and future and, therefore, did not witness to their neighbours. The message of God through the prophet was that the Jews would remain in exile for a long time and that they were to change their disposition adapt to the new situation and seek the interests of the city of Babylon. Pretorius encourages his white readers to get to know the country and its cities in order to be able to seek and pray for its interests and to be prepared for the new South Africa. In the course of his reflection, Pretorius (1993:4-5) makes explicit that his intended reader is white people, or the Christians of the Nederduitse Gereformeerde Kerk (Pretorius 1993:5), or privileged Christians (Pretorius 1993:6-7). He is aware that, whilst there are differences between these readers and the Jews in the time of the prophet Jeremiah, there are key commonalities between them and his intended readers, which means that his intended readers can apply this message to their lives (Pretorius 1993:4-5). He asks the following:

Do we know South Africa? We know the Sun Cities, Orkneys and the Sandtons, but do we know the backyards of South Africa that part of our beautiful land which is not so pretty and is in sharp contrast to the rest, which we know so well? What is our impression of the squatters, for example? If we lie in our warm bath or bed, do we ever think of their calamities? (Pretorius 1993:5)

As guidelines, he suggests the 'old guidelines' of the apostle Paul, who charges his readers firstly to care for the inner circle in their immediate environment, which, for Pretorius, now also includes black fellow Christians. He refers to the role that influential Christians can play to change the circumstances which lead to need. He then charges his readers to move broader, to all people, even though Paul realises the following: ... our patience and ability to live in peace, is limited ... also when
your neighbour is unproductive, set unrealistic demands, and
in their short-sightedness, hurt their own interests. (Pretorius
1993:7)

For this to happen, Pretorius concludes and calls for a 'conversion', an inner change. He charges his readers to think differently from before, also concerning their position of privilege and their role in this country. They are to put themselves in the shoes of their neighbours, and in doing this, they will start to work together in seeking the interests, or shalom, of the city (Pretorius 1993:7).

\section{Reflections}

It would seem from the introduction of this article that, more than 20 years after the end of apartheid, in the 'new South Africa', calamities and injustice continue to keep urban dwellers in their shackles. Many new political and economic realities seems to maintain and entrench the unequal and divided, violent structural realities (Botha 2011:146f.; Mashau \& Kritzinger 2014; Saayman 2008:19-25; Terreblanche 2002). Economist Sampie Terreblanche (2014) refers to South Africa in the title of his recent publication as a Divided country (Verdeelde Land). He also refers to the continuation of the colonial inequalities because of various political-economic elite pacts. This division is reflected in urban realities of which homelessness is a symptom, breeding bitter conflict. This pervasive and powerful social reality is embodied in urban institutions, cultural practices and individual actions in geographical spaces that Swilling, Humphries and Shubane (1991) call the 'apartheid city'. It is not the purpose of this limited contribution to go into the details of how this apartheid city was conceptualised and constructed in order to keep black Africans out (see Kgatla 2013:120-123; Posel 1991:19-32). The reality today, it would seem, is that landlessness and the contestation over ownership of property are still challenging cities like Tshwane and are becoming an acute matter, specifically for migrating communities 
(Mashau 2014:195-199). Seeking the peace of the city, which would go deeper than a mere observation of its challenges, calls for a deeper (radical) structural transformation.

The examples presented so far provide important guidelines, yet they remain reflections from within a particular context. As we assess the reading by the homeless, the question needs to be what their own analysis of their challenges is and how they themselves would read the biblical texts on peace. A second concern regarding these readings is that they remain the product of 'trained' readings. Therefore, they exclude the perspectives, interpretations and existential experiences of the victims of conflict and violence, the poor homeless people themselves. Hence, I proceed to bring these trained readings as well as my own (perhaps subjective) structural analysis in conversation with the perspectives from the streets.

\section{Towards a contextual reading of Ephesians 2:11-22 Methodological considerations}

The particular session with our participants took place at one of the venues of the Tshwane Leadership Foundation in inner-city Tshwane where most of the participants were either hosted temporarily or could walk in. Participants (mostly women) were free to participate, and with the number of younger mothers with small babies, they would often leave the session to attend to their babies and come back later. However, most of those who started the sessions stayed the course. Embracing this reality was a crucial methodological consideration in terms of the specific contextual Bible study proposal by West.

West (2001:169) concedes that 'all Bible study is contextual', but he explains that his proposal is about 'commitment rather than cognizance to context'. He then continues by pointing out that it is a commitment to the particular context of the poor and marginalised (West 2001:169). The 'struggles around race, class, culture, and gender - in their specifically South African manifestations', forged contextual Bible study (West 2001:170). He frames contextual Bible study in the broader liberationist and Kairos tradition. Yet for him, the Kairos Document itself offered little in terms of a process. This is why '... it was in the small hesitant and heuristic steps that groups of ordinary black African Bible readers and socially engaged scholars began to meet and read the Bible together' (West 2001:171). Such a methodology, he argues, holds the promise of a "conversion "from below" in which the biblical scholar becomes partially constituted by the experiences and struggles of the poor and marginalised' (West 2001:172-173). This was our experience with the homeless, mostly women (and some men) from various Southern-African countries and rural communities as we explored and experienced with them their immediate realities, challenges and agency but also the meaning of the text in these sessions.

West (2001:173-180) refers to a few key considerations which guided my preparation and facilitation. The workshop was to be on a theme or issue that we thought to be of vital concern to the group. The actual Bible Study was to be one of the activities (like sharing a meal together). The process is communal, which includes the local community resources as well as the interpretative tools of biblical scholars in a collaborative sharing of skills and resources.

In the introduction, I, as the facilitator, explained what the subtheme for the session would be, namely 'Going beyond the absence of violence towards true peace and reconciliation'. I further explained that we would use the pericope of Ephesians 2:11-22. Consequently, the aforementioned text was read aloud to and with the whole group. In a second round, the text was read in small groups individually, and the group-members were to share in their small group what they thought the text was about. Every group then presented feedback to the larger group, summarising the essence of their discussions, and the feedback was written on newsprint. Following this, particular questions were discussed in the small groups, and the discussions were written down and presented to the whole group. The following questions were discussed:

1. Who are the intended readers of the letter, and what do these verses say about how they viewed themselves ('aliens' and 'sojourners')? How does that make you feel?

2. What does the author want to communicate about Jesus Christ and his purpose?

3. What is the 'dividing wall of hostility' (NIV)?

4. How does Jesus Christ impact on the self-identity of the intended readers? How does that make you feel?

5. What are the images that the author uses to depict his readers? How does that make you feel?

Discuss: Where do I find myself in this city (of Tshwane)? What are the dividing walls? Where is Jesus in this city today?

\section{A reading from the streets}

The first discussion was about the introduction and started to move towards and to focus on the question about the overall theme of the text. The different groups (GR) responded as indicated below, bearing in mind that the recorder aimed at all times to capture the findings as best as possible. For these groups, there seemed to be consensus that the theme revolves around the idea of unity, the bringing together of groups that were previously separated.

Responses to question one:

- 'We are all one Christ [sic] whether we are Jews or Gentiles.' (Gr 1)

- 'Gentiles are now being recognised as the Children of God.' (Gr 2)

- 'Show how Jesus Christ brought together nations or tribes into a single community called Christians.' (Gr 3)

On the question concerning theidentity of theintended readers of that particular passage and how they saw themselves, the groups agreed that the apostle Paul was the author, but they 
differed in terms of who the intended readers were. Some felt that it was the gentiles, others preferred the church in Ephesus. The theme of being 'inferior' in comparison to another group emerged strongly.

\section{Responses to question two:}

- 'Paul wrote the letter to the Gentiles of Ephesus. They saw themselves as lesser human beings (inferior).' (Gr 1)

- 'The letter was written by Apostle Paul for the church of Ephesus. Paul was informing that they are now because of the blood of Christ are sons \& daughters of God, they mustn't see themselves as Gentiles; saved by grace not by circumcision or now circumcision or race through faith.' (Gr 2)

- 'The intended recipients of the letter of Paul were the Gentile community in the city of Ephesus. They saw themselves as inferior amongst the Jews.' (Gr 3)

The next question was: What did Jesus come to do in that context? The following responses were recorded, and they highlighted unity.

\section{Responses to question three:}

- 'Jesus came to unite humanity regardless of their different standings in the society. He came to show that all human beings are equal and that there is none who is more equal than others. He also came to show love to human beings and show them that they are accepted in front of him.' (Gr 2)

- 'He came to set us free from sin and bondage.' (Gr 1)

- 'Jesus came to be a unifier, presented himself as an epitome of love, forgiveness, peace and humility. His ministry ultimately targeted the walls of prejudice which he intended and finally destroyed.' (Gr 3)

The next question that the groups discussed was: How does the calling of Jesus change the way in which people see themselves?

\section{Responses to question four:}

- 'People realise and gained their self-esteem and confidence.' (Gr 1)

- 'They are now equal with the Jews It gave them a sense of self-worth, and belonging free to communicate with their father through their faith in Jesus Christ. They are now free from the bondage of low self-esteem.' (Gr 2)

- 'Gave them time for self-retrospection as to whom they were coming and joining in their spiritual journey. It gave them hope and purpose and they also rediscovered that at the end they were a single people with the same needs and wants who had been only divided by religious doctrine, tribal and ethnic differences.' (Gr 3)

The next question asked about the new images that Paul used for the intended readers?

Responses to question five:

- 'Offsprings of God and they are part of God. They are citizens of God. They are a column built upon a foundation built by the prophets of God.' (Gr 3)
- 'They are no longer foreigners, strangers. They are children of God. (Gr 2)

- 'Fellow citizens of God's people. Members of the family of God. Sacred temples.' (Gr 1)

The next set of questions focused on the groups themselves, reflecting on their own situation in terms of interpreting the pericope for their own realities. The question they discussed was: Where am I in this story? The responses captured were personal but also reflected on the group or collective experiences.

Responses to question six:

- 'There was a time when she felt that the Bible and Christianity doesn't do it for her. Until the day she realised that Jesus died for us. Jesus has done it therefore we do not have any excuse. Jesus is the cornerstone. We shouldn't judge ourselves by where come from. God is not interested in that therefore it shouldn't affect our self-esteem.' (Gr 1)

- 'V19 'I don't see myself as a Gentile. We get the grace from Jesus Christ through his blood. Its all about Christ and accepting him.' Gal 3:28 (Gr 3)

Question 7 focused outward by asking the following: What is the message for the City of Tshwane? The following were captured as the whole group's responses.

Responses to question seven:

- 'John 3:16: They need to believe in Jesus so they will be free.'

- 'Tshwane people should go out to people in need, just like Jesus did.'

- 'To the people of Tshwane this is an opportunity to be part of God's household. This is a refuge and it is a wonderful opportunity to be part of this household.'

- 'There are circumstances, past, future times that make us think that we are not good enough. Even Paul was a sinner but God chose him. There is no past that will prevent God from choosing you. It doesn't matter where you come from, follow Christ.'

- 'Regardless you are a native or a foreigner we all belong to the human race that belong to Jesus. Whether you are in suburbs, streets, or shelter we all the same value in Jesus. His love is the same.'

\section{Synthesis and a transformative encounter}

Having read the first section of this article as well as the author's (and facilitator's) own theological background and argument, one could dismiss the readings from the street by the specific participants of the Bible study as too individualised and spiritual. In the words of De Villiers, they would seem too focused on an inner peace. This assessment, however, needs to be viewed in the light of the participants' own situation and existential challenges.

In the reading of the participants, the personal as well as the relational dimensions of their reality come into focus, and it relates to the specific context of the participants. This reading is not generic. It sharpens the interpretation (of the 
participants) towards the real challenges that the participants themselves face and also to their efforts at finding meaning and strength through the religious text. Hence, one can discern a particular interpretation of seeking peace, articulated in terms of the following narratives.

Peace, in this reading of the text, is not about the big structural ('political') realities. It is about a personal, internal unshackling from feelings of inferiority or a low self-esteem due to circumstances. The groups live within the context of unequal power relations and are vulnerable, whether it is socially, in terms of their lack of housing, or in families where women still experience the brunt of patriarchy and domestic violence. They have to find ways to survive with their little children. This requires personal, internal freedom from these unequal relations towards an affirmation of their true self. This true self is discovered personally, but it is also affirmed in community. This leads to the next narrative.

Peace is about finding a home or refuge in the new community or household - this is a new blood family by the blood of Jesus Christ. This new community reimagines church in a new way. Being part of this household does not depend on institutional membership or traditional denominationalism. For these groups, it is about affirming a new community through (the blood of) Jesus Christ.

Peace is therefore about unshackling an oppressive identity and about affirming that,

[r]egardless whether you are a native or a foreigner, we all belong to the human race that belong to Jesus. Whether you are in suburbs, streets or a shelter, we all have the same value in Jesus. His love is the same. (From the plenary discussion)

It would seem then, from this reading of Ephesians 2:1122 , that one can critique, on the one hand, a generalised call or preaching for peace which does not take seriously the particular personal as well as communal challenges that are so critical in finding healing and agency to participate meaningfully in community building. On the other hand, the participants' contextual reading seems to suggest that seeking peace does not start with the broader structural realities but, for this group, it starts deep down in the affirmation of a (religious) identity that transcends exclusionary practices and affirms the God-given dignity of the participants. It correlates with Biko's (1978:101-102) notion of consciousness and emphasis on the freedom of the mind.

\section{Conclusion}

Seeking peace, as an internal unshackling from debilitating relationships, and finding it through a contextual reading of religious texts might sound, for a structuralist trained reader, like just another pie in the sky or like framing the urban homeless as an individualised problem. It seems from their own words, however, that this is not the case.
Their contextual reading is not limited to either sharpening the broad, idealistically trained readings or contradicting a particular structural analysis, like that of the author. Rather, it is about affirming their value, as members of the family of God, which subvert and transform exclusivist elite interpretations and practices. It is for them about seeking peace in the affirmation of themselves as the basis for the transformation of these spaces, also in urban centres like Tshwane. This is where, and seemingly how, the various expressions of urban religion can start to seek peace.

\section{Acknowledgements}

This work is based on the research supported by the Meals of Peace Community Engagement project and College of Human Sciences (CHS), University of South Africa. Any opinion, finding and conclusion or recommendation expressed in this material is that of the author. The CHS, University of South Africa do not accept any liability in this regard.

\section{Competing interests}

The author declares that he has no financial or personal relationships which may have inappropriately influenced him in writing this article.

\section{References}

Bakke, R., 1989, 'Overcoming the real barriers', in I. Coffey \& G. McKinney (eds.), No stranger in the city: God's concern for urban people, pp. 41-52, Inter-Varsity Press, Leicester.

Bekker, S., 1991, 'Cities straddling homeland boundaries', in M. Swilling, R. Humphries \& K. Shubane (eds.), pp. 108-118, Apartheid city in transition, Oxford University Press, Cape Town.

Biko, S., 1978, I write what I like, Picador Africa, Johannesburg.

Botha, N.A., 2011, 'Living at the edge of empire: Can Christianity prevail and be effective? A theological response to the historical struggle between empire and Christianity', Studia Historiae Ecclesiasticae 37(3), 133-155.

Burger, C.W., Müller, B.A. \& Smit D.J. (eds.), 1990, Riglyne vir prediking oor vrede, Lux Verbi, Cape Town.

Davenport, R., 1991, 'Historical background of the apartheid city to 1948', in M. Swilling, R. Humphries \& K. Shubane (eds.), pp. 1-18, Apartheid city in transition, Oxford University Press, Cape Town.

De Villiers, D.E., 1990, 'Die predikingoorvrede', in C. Burger, B. Müller \& D.J. Smit (reds.), Riglyne vir prediking oor vrede, bl. 11-20, Lux Verbi, Kaapstad.

Eliseev, A., 2008. 'A narrative of violence', in S. Hassim, T. Kupe \& E. Worby (eds.), Go home or die here: Violence, xenophobia and the reinvention of difference in South Africa, pp. 27-40, Wits University Press, Johannesburg.

Hassim, S., Kupe, T. \& Worby, E. (eds.), 2008. Go home or die here: Violence, xenophobia and the reinvention of difference in South Africa, Wits University Press, Johannesburg.

James, G., 2008, 'Due south: The challenges and opportunities of African migrancy in South Africa', in D. de Gruchy, N. Koopman \& S. Strijbos (eds.), From our side: Emerging perspectives on development and ethics, pp. 61-74, Rozenberg side: Emerging perspectives
Publishers, Bloemgracht.

Kgatla, S.T., 2013, 'Forced removals and migration: A theology of resistance and liberation in South Africa', Missionalia 41(2), 120-132. http://dx.doi. org/10.7832/41-2-9

Kritzinger, J.N.J., 2008, 'Faith to faith: Missiology as encounterology', Verbum et Ecclesia 29(3), 764-790. http://dx.doi.org/10.4102/ve.v29i3.31

Landau, L., 2008, 'Violence, condemnation, and the meaning of living in South Africa', in H. Hassim, T. Kupe \& E. Worby (eds.), Go home or die here: Violence, xenophobia and the reinvention of difference in South Africa, pp. 106-110, Wits University Press, Johannesburg.

Mangayi, C., 2014, 'Poverty, marginalisation and the quest for collective wellbeing in the context of homelessness in the City of Tshwane', Missionalia 42(3), 212-235. http://dx.doi.org/10.7832/42-3-64

Mashau, T.D., 2014, 'More than just a piece of land: Power dynamics in the land discourse within the City of Tshwane', Missionalia 42(3), 192-211. http://dx.doi. org/10.7832/42-3-64

Mashau, T.D. \& Kritzinger, J.N.J. (eds.), 2014, Pavement encounters towards justice, AcadSA Publications, Cape Town. 
Orobator, A.E., 2005, From crisis to Kairos: The mission of the church in the time of HIV/ AIDS, refugees and poverty, Paulines Publications Africa, Nairobi.

Posel, D., 1991, 'Curbing African urbanisation in the 1950s and 1960s', in M. Swilling R. Humphries \& K. Shubane (eds.), Apartheid city in transition, pp. 19-32, Oxford University Press, Cape Town.

Pretorius, H.L., 1993, 'Soek die belange van die stad', in G. van Rooyen (ed.), Die belange van die stad: Oordenkings en Bybelstudie oor die getuienistaak van die kerk in ' $n$ veranderende Suid Afrika, pp. 1-7, S.n., Greytown.

Rademeyer, J., 2007, 'Young, gifted and bad', Sunday Times, 04 February, p. 6.

Saayman, W., 2008, "'The sky is red, so we are going to have fine weather": The Kairos document and the signs of the times, then and now', Missionalia 35(1), 16-28.

Segovia, F.F., 1999, 'Postcolonial and diasporic criticism in Biblical studies: Focus, parameters, relevance', Studies in World Christianity 5(2), 177-195. http://dx.doi. org/10.3366/swc.1999.5.2.177

Silverman, M. \& Zack, T., 2008, 'Housing delivery, the urban crisis and xenophobia', in S. Hassim, T. Kupe \& E. Worby (eds.), Go home or die here: Violence, xenophobia and the reinvention of difference in South Africa, pp. 147-159, Wits University Press, Johannesburg.
Speckman, M.T. \& Kaufman, L.T. (eds.), 2001. Towards an agenda for contextual theology: Essays in Honour of Albert Nolan. Cluster Publications, Pietermaritzburg.

Sugirtharajah, R.S., 2003, Postcolonial reconfigurations: An alternative way of reading the Bible and doing theology, SCM Press, London.

Swilling, M., Humphries, R. \& Shubane, K. (eds.), 1991, Apartheid city in transition, Oxford University Press, Cape Town.

Terreblanche, S., 2002, A history of inequality in South Africa 1652-2002, University of KwaZulu-Natal Press, Pietermaritzburg.

Terreblanche, S., 2014. Verdeelde land: Hoe die oorgang Suid-Afrika faal, Tafelberg, Cape Town. (Kindle edn.)

Tshwane Leadership Foundation, viewed 03 August 2015, from http://www.tlf.org.za/

Van Rooyen, G.H., 1993, Die belange van die stad: Oordenkings en Bybelstudie oor die getuienistaak van die kerk in 'n veranderende Suid Afrika, S.n., Greytown.

West, G., 1993, Contextual Bible study, Cluster Publications, Pietermaritzburg.

West, G., 2001, 'Contextual Bible study in South Africa: A resource for reclaiming and regaining land, dignity and identity', in M. Speckman \& L. Kaufman (eds.), Towards an agenda for contextual theology: Essays in Honour of Albert Nolan, pp. 169184, Cluster Publications, Pietermaritzburg. 